plant pathogenic fungi. International Journal of Biological Macromolecules 2016, 82, 830836.

8. Tan, C.; Xie, J.; Zhang, X.; Cai, J.; Xia, S. Polysaccharide-based nanoparticles by chitosan and gum arabic polyelectrolyte complexation as carriers for curcumin. Food Hydrocolloids 2016, 57, 236-245.

9. Van, S. N.; Minh, H. D.; Anh, D. N. Study on chitosan nanoparticles on biophysical characteristics and growth of Robusta coffee in green house. Biocatalysis and Agricultural Biotechnology 2013, 2, 289-294.

10. Saharan, V.; Mehrotra, A.; Khatik, R.; Rawal, P.; Sharma, S.; Pal, A. Synthesis of chitosan based nanoparticles and their in vitro evaluation against phytopathogenic fungi. InternationalJournalofBiologicalMacromolecules 2013, 62, 677-683.

11. Manikandan, A.; Sathiyabama, M. Preparation of Chitosan nanoparticles and its effect on detached rice leaves infected with Pyriculariagrisea. InternationalJournalofBiologicalMacromolecules 2016, 84, 58-61.

DOI 10.18699/GPB2020-104

\title{
Статус и вариабельность серы (S и N:S) в зерне сортов яровой мягкой пшеницы
}

Савин Т.В. ${ }^{\text {* }}$, к.б.н.; Абугалиева А.И. ${ }^{2}$, д.б.н., профессор; Чакмак И. ${ }^{3}$, профессор. ${ }^{\prime}$ ТОО «Карабалькская СХОС», пос. Научное, Казахстан;

${ }^{2}$ ТОО КазНИИЗиР», Алмалььбак, Казахстан;

${ }^{3}$ Сабанчи Университет, Стамбул, Туричия.

*e-mail: savintimur_83@mail.ru

Cтатус серы (содержание серы и соотношение $N: S$ ) детерминирован генотипически (сорт) и зависит от условий региона воздельввания. Bыявлены регионы и сорта дефицитные и критичные по содержанию серы, что влияет на формирование качества зерна яровой пиеницьы.

Ключевые слова: Сера, N:S, качество зерна, сортовой генофонд, яровая пиеница.

\section{$\mathrm{S}$ and $\mathrm{N}: \mathrm{S}$ in the grain quality classification in spring wheat cultivars}

Savin T.V., PhD, Karabalyk Research Station_LPP, savintimur_83@mail.ru Abugalieva A.I. prof., Kazakh research Institute of Agricultural Plant Growing, Almalybak, Kazakhstan

Chakmak I, prof, Sabanchi University, Istanbul, Turkey.

Sulfur status (sulfur content and $N$ : $S$ ratio) is genotypically determined (type) and depends on the conditions of the cultivation region. Identified regions and varieties deficit and reviews of sulfur content, which affects the quality of spring wheat grain. 
Sulfur, N: S, grain quality, varietal gene pool, spring wheat.

Известно, что питательный режим пшеницы серой (S) оказывает важное влияние на хлебопекарные свойства муки, через существенную роль дисульфидных связей в обеспечении функциональности клейковины. Значение $\mathrm{S}-\mathrm{S}$ связей связано со свойствами упругости и эластичности и балансом формирования S-бедных белков ( $\omega$-глиадины, BMC-глютенины) и S-богатых ( $\alpha$, $\gamma$-глиадины и НМС-глютенины), в том числе на уровне глиадиновых биотипо [цит 1].

Потребность пшеницы в сере не так велика: порядка 20 кг S/га для среднего урожая 8 т/га. В ряде работ показан статус $\mathrm{S}$ (содержание $\mathrm{S}$ и соотношение $\mathrm{N}: \mathrm{S}$ ) как важного фактора влияющего на хлебопекарные качества муки. В то же время A.R.Wooding et. al. [цит 1] считают, что для хлебопекарных свойств $\mathrm{N}: \mathrm{S}=12,5: 1$ является оптимумом, а при $>13: 1$ требуются дополнительные затраты на перемешивание теста. Структурно 1 часть $\mathrm{S}$ требует 15 частей $\mathrm{N}$. Если $\mathrm{S}$ в дефиците вследствие применения $\mathrm{N}$ удобрений, аккумуляция непротеиновых компонентов, таких как амиды приводит к увеличению $\mathrm{N}: \mathrm{S}$ к более чем 15:1. Сравнение суммарного $\mathrm{N}$ и $\mathrm{S}$ и белкового N:Sпозволяет получить полезную информацию о питательном балансе между $\mathrm{N}$ и $\mathrm{S}$ в растениях и использовать в диагностике статуса S. Отмечена тенденция, что со временем уменьшается содержание S (1992-1993 - 1,35 мг/г, 1981-1982 - 1,72 мг/г) и $\mathrm{N}: \mathrm{S}$ возрастает с 12:1 и до 16:1. Содержание $\mathrm{S}$ в лимите на втором месте после N (например, на севере Германии). Критически дефицитным считается содержание S 1,2 мг/г и 17:1 (N:S) [цит 1].

Цель исследований: определить статус $\mathrm{S}$ (содержание $\mathrm{S}$ и соотношение $\mathrm{N}: \mathrm{S}$ ) в зерне коммерческих и перспективных сортов пшеницы в яровосеющих регионах Казахстана.

Материал и методы исследований: зерно 1550 образцов сортов яровой мягкой пшеницы различного происхождения, испытываемые в Казахстане.

Полевые методы и методы отбора проб, согласно ГОСТ 13586.3-83; содержание протеина - ГОСТ 10846-91. Содержание S в зерне и в муке определены методами атомной адсорбции и спектральным: индуктивно плазменно-атомной эмиссионной спектрометрии (ICPAES) на базе Сабанчи Университета г.Стамбул, Турция.

В Казахстане ранее изучены коммерческие и перспективные сорта озимой мягкой пшеницы со спектром изменчивости серы (1005-1818 мг/кг) в зерне в зависимости от сорта и региона, и соотношения $\mathrm{N}: \mathrm{S} 18,6: 1$ до 20,9:1 на фоне диких сородичей и гибридов с ними [1], в сравнительном плане с пшеницами Средней Азии. По яровой мягкой и твердой пшенице изучены синтетики на фоне диких сородичей и сортов , дигаплоидные линии популяции CSxSQ [2] в условиях Юго-востока и в сети КАСИБ в условиях 4-ех регионов Казахстана. 
Известно, что качество белка зависит от содержания S-S связей и в целом содержания серы. Анализ DH-линий позволил выявить повышенное содержание $\mathrm{S}$ (более 2000 мг/кг) в сравнении с районированными сортами яровой пшеницы в Казахстане. Причем, выявлены линии стабильно формирующие высокий уровень S (DH-9; DH-54) во всех условиях и DH-128 в условиях богары. Вклад генетического фактора на формирование S в зерне достигает $94 \%$.

Яровые синтетики отличались широким диапазоном изменчивости содержания серы в зерне в повышенном фоне (1740-2506 мг/кг) для Казахстанская $\mathrm{p} / \mathrm{c}$ х $T$. timopheevii и практически для всех гибридов с T. timopheevii (2443 мг/кг) и T. militinae (2275 мг/кг) [1].

Анализ сортового генофонда по содержанию $\mathrm{S}$ в зерне яровой мягкой пшеницы выявил варьирование от 1179 мг/кг до 2359 мг/кг для сорта Павлодарская 93 в условиях Алгинского ГСУ, ЗКО.

Регионы дифференцированы по содержанию $\mathrm{S}$ в зерне на группы: 1) с высоким содержанием серы в минимальных, максимальных и средних значениях: Сырымский (1634-2176 мг/кг); Шалакынский (1530-2021 мг/кг); Зеленовский (1544-1943 мг/кг); Жана-Аркинский (1518-2021 мг/кг), Павлодарский (1541-1954 мг/кг); 2) с низким содержанием серы в регионах Мартукский (1179-1653 мг/кг при срднем 1376 мг/кг); Каркаралинский (1291-1537 мг/кг) при среднем 1360 мг/кг); Иртышский (1273-1594 мг/кг при среднем 1400 мг/кг) и Новопокровский (1249-1691 мг/кг при среднем 1435 мг/кг).

Абсолютно максимальными значениями выше 2000 мг/кг содержанием серы выделяются сорта: Павлодарская 93, Казахстанская раннеспелая, Актюбе 39, Лютесценс 32, Саратовская 29. Абсолютно минимальные значения характерны для сортов Вера, Бражинская, Карабалыкская 92, Саратовская 55, Целинная 26 и Алтайская 60 (табл. 1).

Таблица 1 - Характеристика сортов яровой мягкой пшеницы по содержанию $\mathrm{S}$ в зерне и его изменчивости в зависимости от условий и репродукции

\begin{tabular}{|c|c|c|c|c|c|c|c|c|c|}
\hline \multirow[b]{2}{*}{ Сорт } & \multirow{2}{*}{ 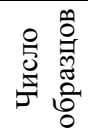 } & \multirow[b]{2}{*}{$\min$} & \multirow[b]{2}{*}{$\max$} & \multirow[b]{2}{*}{ среднее } & \multicolumn{5}{|c|}{ Доля генотипов с содержанием S } \\
\hline & & & & & $\stackrel{>}{2000}$ & $\begin{array}{l}1999- \\
1800\end{array}$ & $\begin{array}{l}1799 \\
1600\end{array}$ & $\begin{array}{l}1599- \\
1400\end{array}$ & $\begin{array}{l}1399- \\
1200\end{array}$ \\
\hline 1 & 2 & 3 & 4 & 5 & 6 & 7 & 8 & 9 & 10 \\
\hline Астана & 9 & 1369 & 1986 & 1728 & - & 33,0 & 45,0 & 11,0 & 11,0 \\
\hline Алтайская 50 & 2 & 1654 & 1862 & 1758 & - & 50,0 & 50,0 & - & - \\
\hline Алтайская 60 & 4 & 1299 & 1648 & 1472 & - & - & 25,0 & 50,0 & 25,0 \\
\hline Бражинская & 3 & 1228 & 1545 & 1413 & - & - & - & 67,0 & 33,0 \\
\hline Bepa & 3 & 1232 & 1454 & 1378 & - & - & - & 67,0 & 33,0 \\
\hline Карабалыкская 92 & 6 & 1284 & 1574 & 1396 & - & - & - & 50,0 & 50,0 \\
\hline $\begin{array}{l}\text { Казахстанская } \\
\text { раннеспелая }\end{array}$ & 18 & 1348 & 2021 & 1651 & 6,0 & 11,0 & 44,0 & 33,0 & 6,0 \\
\hline Лютесценс 32 & 5 & 1495 & 1964 & 1800 & - & 60,0 & 20,0 & 20,0 & - \\
\hline
\end{tabular}




\begin{tabular}{|l|c|c|c|c|c|c|c|c|c|}
\hline \multicolumn{1}{|c|}{$\mathbf{1}$} & $\mathbf{2}$ & $\mathbf{3}$ & $\mathbf{4}$ & $\mathbf{5}$ & $\mathbf{6}$ & $\mathbf{7}$ & $\mathbf{8}$ & $\mathbf{9}$ & $\mathbf{1 0}$ \\
\hline Павлодарская 93 & 9 & 1270 & 2359 & 1692 & 22,0 & 11,0 & 11,0 & 34,0 & 22,0 \\
\hline Саратовская 29 & 18 & 1278 & 2021 & 1615 & 6,0 & 11,0 & 33,0 & 28,0 & 22,0 \\
\hline Саратовская 55 & 6 & 1250 & 1640 & 1460 & - & - & 17,0 & 50,0 & 33,0 \\
\hline Целинная 26 & 7 & 1260 & 1710 & 1473 & - & - & 29,0 & 29,0 & 42,0 \\
\hline
\end{tabular}

Критичность и дефицит серы в зерне рассматривается по соотношению с азотом: это соотношение 17:1 до 19:1 и более. Дифференциация регионов затруднительна по данным ГСИ, т.к. в испытании задействованы разные сорта.

В отдельных географических точках максимальные значения N:S превышают порог дефицита для некоторых сортов: это Есильский $(19,8: 1)$; Щучинский $(19,9: 1)$ и Костанайский ГСУ.

В диапазон критичного значения N:S (17-19:1) попадают регионы Новопокровский (60\% всех генотипов в этой точке); Камышинский (57\%); Шортандинский (50 \%); Щучинский (36 \%); Рузаевский (25\%); Жаксынский $(29 \%)$.

Таким образом, по соотношению $\mathrm{N}: \mathrm{S}$ (17-19:1) к критичным по содержанию S можно отнести Нопокровский, Камышинский, Шортандинский и Щучинский ГСУ, в условиях которых зерно 43-60 \% сортов отличаются дефицитом серы. Для Новопоровского ГСУ это согласуется с данными по содержанию S в зерне. Для Иртышского, Каркаралинсколго и Мартукского, минимальные значения S (1200 мг/кг) являются не критичными, т.к. соотношения $\mathrm{N}: \mathrm{S}$ находится в оптимуме до 17:1.

Сорта с максимальным значением N:S выше чем 19:1 в данном испытании это: Росинка 3, Омская 24 (19,9:1); Омская 18 (19,8:1); Карабалыкская $90(19,2)$; Дарина $(18,8: 1)$ и Казахстанская 19 (18,5:1). Последние 2 сорта характеризуются высокой долей генотипов с дефицитом серы по минимальным и средним значениям (табл. 3). Достаточно высокая доля генотипов с дефицитом серы формируется для сортов Шортандинская 95 улучшенная (40 \%); Росинка 3 и Любава (25\%); Лютесценс 694 (33 \%); Карабалыкская $90(29 \%)$ и Кенжегали (31\%).

Таблица 2 - Характеристика сортов яровой мягкой пшеницы по содержанию $\mathrm{N}: \mathrm{S}$ в зерне и его изменчивости в зависимости от условий и репродукции

\begin{tabular}{|c|c|c|c|c|c|c|c|}
\hline \multirow{2}{*}{ Сорт } & \multirow{2}{*}{$\begin{array}{c}\text { Число } \\
\text { образцов }\end{array}$} & \multirow{2}{*}{$\min$} & \multirow{2}{*}{$\max$} & \multirow{2}{*}{ среднее } & \multicolumn{3}{|c|}{ Доля генотипов с N:S } \\
\hline & & & & & $13-15$ & $15,1-17,0$ & $17,1-19,0$ \\
\hline 1 & 2 & 3 & 4 & 5 & 6 & 7 & 8 \\
\hline Дарина & 7 & 17,0 & 18,8 & 17,9 & - & 14 & 86 \\
\hline Карабалыкская 90 & 17 & 14,2 & 19,2 & 16,1 & 6 & 65 & 29 \\
\hline Казахстанская 19 & 4 & 16,7 & 18,5 & 17,6 & - & 25 & 75 \\
\hline Кенжегали & 3 & 15,0 & 18,0 & 16,4 & 33 & 33 & 34 \\
\hline Любава & 12 & 13,9 & 18,3 & 15,7 & 50 & 25 & 25 \\
\hline Омская 18 & 20 & 13,3 & 19,8 & 15,5 & 40 & 40 & 20 \\
\hline
\end{tabular}




\begin{tabular}{|l|c|c|c|c|c|c|c|}
\hline \multicolumn{1}{|c|}{$\mathbf{1}$} & $\mathbf{2}$ & $\mathbf{3}$ & $\mathbf{4}$ & $\mathbf{5}$ & $\mathbf{6}$ & $\mathbf{7}$ & $\mathbf{8}$ \\
\hline Омская 24 & 9 & 14,7 & 19,9 & 16,2 & 22 & 67 & 11 \\
\hline Росинка 3 & 8 & 14,4 & 19,9 & 16,2 & 25 & 50 & 25 \\
\hline $\begin{array}{l}\text { Шортандинская 95 } \\
\text { улучшенная }\end{array}$ & 5 & 15,0 & 17,5 & 16,3 & 20 & 40 & 40 \\
\hline
\end{tabular}

Выводы. Содержание серы и соотношение N:S детерминировано генотипически и зависит от условий региона возделывания. Выявлены регионы и сорта дефицитные и критичные по содержанию серы, что влияет на формирование качества зерна яровой пшеницы. Соответственно, применение удобрений для улучшения качества зерна и муки должно учитывать специфичность генотипа, среды и их взаимодействия в рамках разработки сортовых технологий [3].

\section{Список литературь}

1. Abugalieva A., Savin T., Chakmak I., Kozhakhmetov K., Chudinov V., Morgunov A. Grain mineral composition of introgressive wheat-wild forms in breeding of spring wheat on the nutritional properties // News of the National Academy of sciences of the republic of Kazakhstan, series of Agricultural sciences. - Vo., N.1. - 2019. - P. 27-38.

2. Абугалиева А.И., Абугалиева С.И., Кворри С.А., Туруспеков Е.К., Чакмак И., Савин T.B., Ганеев B.A. Содержание $\mathrm{Fe}, \mathrm{Zn}$ и S в зерне популяции дигаплоидных линий мягкой пшеницы Chinese spring x SQ1 // Вавиловский журнал генетики и селекции. - 2012. - Т. 16. - № 4/2. - С. 894-901.

3. Hrivna L., Kotkova B., Buresova L. Effect of sulphur fertilization on yield and quality of wheat grain // Cereal Research Communications. 2015. 43: 344-352.

DOI $10.18699 /$ GPB2020-105

\section{Изучение исходного материала сортообразцов чечевицы в условиях Алматинской области}

Сайкенова А.Ж. ${ }^{1 *}$, м.н.с.; Кудайбергенов M.C. ${ }^{l}$, д.б.н., г.н.с.; Дидоренко С.В. ${ }^{l}$, к.б.н., зав. отделом зернобобовых культур; Сайкенов Б.Р. ${ }^{2}$, к.с.-х.н., профессор. ${ }^{1}$ ТОО «Казахский научно-исследовательский институт земледелия и растениеводства», с. Алмальбак, Республика Казахстан;

${ }^{2}$ Казахский национальный аграрный университет, г. Алматы, Республика Казахстан.

*e-mail:alma.arai@mail.ru

В статье приведень результать изучения 35 зарубежных $u$ отечественных сортов и сортообразиов чечевищы в условиях Алматинской области. Приводятся данные по фазам развития и признакам продуктивности чечевиџы. Также выделены образиы по хозяйственно-иенным признакам и свойствам, которые можно использовать в селекиионных программах. 